\title{
A COMPARATIVE STUDY OF CROSS-FINGER FLAP VERSUS SPLIT-THICKNESS SKIN GRAFT FOR RESURFACING OF SOFT TISSUE LOSS IN FINGERTIP INJURY
}

\author{
Radharaman Panda ${ }^{1}$
}

${ }^{1}$ Former Assistant Professor, Department of General Surgery, Late Sri Lakhiram Agrawal Memorial Government Medical College, Raigarh.

ABSTRACT

\section{BACKGROUND}

Different types of Fingertip injuries are found in human population and different modalities of treatment options are available. Results of the treatment vary according to the mode of treatment. In our institute, we prefer cross-finger flap coverage for composite tissue loss of fingertip defect.

The aim of the study is to find out long-term result of cross-finger flap in comparison with STSG.

\section{MATERIALS AND METHODS}

The study was conducted between November 2014 and October 2016 in Late Sri Lakhiram Agrawal Memorial Govt. Medical College Hospital. It was a time bound, prospective comparative study. It was non-randomised, as patients were segregated into Group A [cross-finger flap (CFF)] and Group B [Split thickness skin graft (STSG)] based on their choice.

\section{RESULTS}

Results were assessed in terms of duration of surgery, length of stay, durability, resistance to normal stress injury, finger stiffness and aesthetic acceptance of repaired area of finger and touch sensation.

\section{CONCLUSION}

Duration of surgery was assessed at the time of surgery between cross-finger flap and STSG groups. Length of hospital stay was assessed and noted postoperatively. Functional outcome was assessed after discharge and followup of patients. Operative time for CFF was more than for STSG. Duration of hospital stay in patients treated with CFF than STSG was same. Functional outcome at 12 months was better in CFF. Durability, resistance to injury in normal stress and aesthetic acceptance and sensory function was better in CFF as compared with STSG.

\section{KEYWORDS}

Cross-Finger Flap, Split-Thickness Skin Graft.

HOW TO CITE THIS ARTICLE: Panda R. A comparative study of cross-finger flap versus split-thickness skin graft for resurfacing of soft tissue loss in fingertip injury. J. Evolution Med. Dent. Sci. 2017;6(84):5904-5910, DOI: 10.14260/jemds/2017/1284

\begin{tabular}{|c|c|}
\hline BACKGROUND & advancement \\
\hline Hand is both an organ designed to obtain information and an & flap $[9,10,11,12,13,14,15,16,17]$ and homodigital neurovascular flap. ${ }^{[18]}$ \\
\hline organ of execution. Fingers are integral part of hand. & In consultation with patient, every surgeon must choose \\
\hline $\begin{array}{l}\text { Different functions help us to perform our normal activity, } \\
\text { especially thumb contributes maximum than other fingers for }\end{array}$ & $\begin{array}{l}\text { the type of coverage that appears to be most appropriate for } \\
\text { that individual's need. }\end{array}$ \\
\hline functioning of hand. Fingertip helps to do fine things, to grasp & Aim of the study was to find out long-term result of cross- \\
\hline
\end{tabular}

Fingertip injury commonly occurs at home, usually in children during playing and accidentally during closure of door. Many interesting techniques have been devised to ensure coverage of exposed bone or soft tissue. There are no definite rules that serves as a satisfactory guide to the choice of each of the technique. Different methods adopted for treatment of fingertip injury are secondary healing, ${ }^{[1]}$ semiocclusive dressing, ${ }^{[2]}$ split-thickness skin graft and local flap coverage. ${ }^{[3]}$ Local flap coverage like V-Y pasty, ${ }^{[4,5]}$ Volar

'Financial or Other Competing Interest': None.

Submission 21-09-2017, Peer Review 13-10-2017,

Acceptance 16-10-2017, Published 23-10-2017.

Corresponding Author:

Dr. Radharaman Panda,

Former Assistant Professor,

Department of General Surgery,

Late Sri Lakhiram Agrawal Memorial

Government Medical College,

Raigarh, Chhattisgarh.

E-mail: drradharaman@yahoo.co.in

DOI: $10.14260 /$ jemds $/ 2017 / 1284$

\section{MATERIALS AND METHODS}

The study conducted was comparative, time bound and hospital based. It was non-randomised as patients were segregated into Group A [cross-finger flap (CFF)] and Group B [split-thickness skin graft (STSG)] based on their choice. This study was carried out in the Department of General Surgery at Late Sri Lakhiram Agrawal Memorial Government Medical College, which is a tertiary care referral teaching hospital. All patients above 10 years of age with fresh fingertip injury were included by the author irrespective of the cause of injury and type of injury between November 2014 and October 2016. During the study period, we were able to enrol 72 patients operated either by cross-finger flap or by splitthickness skin graft (36 subjects in each group).

Patients with active infection, concurrent serious medical illness, non-traumatic disorders and phalanx bone fracture were excluded from the study. All patients who came to the hospital were initially evaluated properly, a written consent was taken for surgery and then posted for surgery. Options 


\section{Study Procedure}

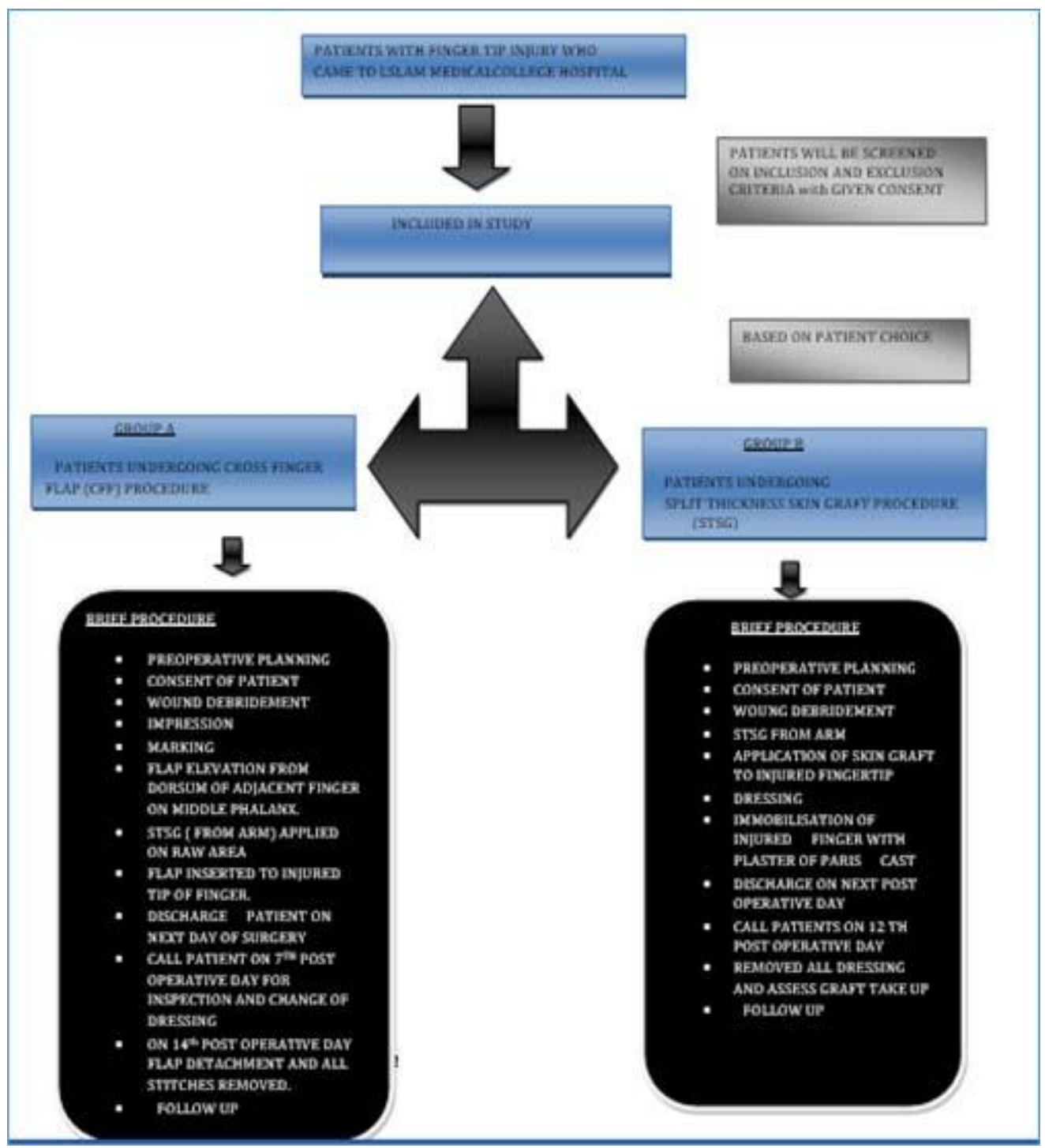

\section{Study Outcomes and Measurement}

Duration of surgery was assessed at the time of surgery between cross-finger flap and split thickness skin graft groups. Length of hospital stay was assessed and noted postoperatively. Sensation, pinching, stiffness of finger, durability and contour and aesthetic acceptance of patients was assessed at regular followup intervals of 1 month up to 6 months and every 3 months up to 12 months of postoperative period respectively.

Chi-square test was used to assess final outcome of patients between the two groups.

\section{Study Analysis Plan}

Descriptive statistics with demographic details of study patients was generated by using software SPSS statistics version 1.0 with respect to age, gender, duration of surgery, side of hand, finger involved and length of hospital stay for the two procedures was compared.

Data at regular followup intervals postoperative 1 month, 2 months, 3 months, 4 months, 5 months, 6 months, 9 months and 12 months were collected to assess the functional outcome. They were compared using appropriate statistical tests.

Chi-square test was used to ascertain the statistical significance in the differences of the categorical variables and independent test was used for continuous variables. P value is considered significant if it was $<0.05$.

\section{Procedure for Cross-Finger Flap Surgery}

Surgery was performed under regional block (brachial plexus block) or under general anaesthesia as per patient's choice of anaesthesia and fitness of patient. Wound of fingertip (Fig. 1 and 1a) was debrided and prepared for coverage of flap from the dorsal surface of middle phalanx of adjacent finger. Injured fingertip area impression was taken by a gauze and put on dorsum of adjacent finger of middle phalanx and marking was done by methylene blue ink (Fig. 2). Normal saline was injected subcutaneously to the marking area for easy plane of dissection and to prevent damage to tendon sheath. From dorsal surface of middle phalanx of finger, flap was elevated just like open book just above the plane of tendon sheath (Fig. 3). Split thickness skin graft (STSG) was taken from prepared area of dorsal surface of arm and 
applied over the raw area of dorsum of middle phalanx of finger, STSG fixed with 5 - 0 cutting silk suture and tied over bolus dressing done. Elevated flap was applied on injured fingertip and sutured by 5 - 0 silk surrounding the margin of wound (Fig. 4). Both fingers were closely kept and bolus sterile dressing was done and hand was covered with sterile dressing. Patient was discharged on next day of surgery and called for followup on 7 th day and 14th day of post-surgery. Operated area was inspected on $7^{\text {th }}$ day and dressing changed. On 14th day of post-surgery (Fig. 5 and 6), flap detachment and refastening was done under local digital block. Grafted area was inspected and all skin stitches removed and kept open. Bandage of donor area of skin graft comes out automatically with healthy operated area.

After 21 days of surgery, all areas of surgery were healed completely and without any defect. All patients were called for followup (Fig. 7) regularly every month up to 6 months and every 3 months till 1 year during the study period. During followup period, history was taken about injury to operated area with normal stress, observation and clinical examination like sensation of operated fingertip, pinching action of fingers, contour of tip of finger and stiffness of fingers of operated hand. Patient's aesthetic acceptation data was collected by asking question to patient whether satisfied or not.

\section{Procedure for Split-Thickness Skin Graft (STSG) and Followup}

As per choice of patient, surgery was done under regional block. Wound of injured fingertip (Fig.) was debrided and STSG was taken from forearm and applied over raw area of finger. Graft was fixed by stitching with margin of wound and tie over bolus dressing done, operated finger was immobilised by plaster of Paris posterior slab for 12 days. Patient was discharged on next day of surgery with advice and called for followup on $12^{\text {th }}$ post-operative day. On $12^{\text {th }}$ post-operative day, dressing was removed and found healthy and kept open. Patient was followed up regularly every month during the study period.

\section{RESULTS}

\section{Demographic Data}

In this study, the minimum age of the patient was 10 years and maximum was 51 years. Out of 72 patients, 52 were male, 20 were female patients, which accounts for $72.22 \%$ and $27.77 \%$ respectively. Mean age is 27.111 years and standard deviation was 10.22501 [Table 1].

\begin{tabular}{|c|c|c|}
\hline $\begin{array}{c}\text { Number of } \\
\text { Patients }\end{array}$ & $\begin{array}{c}\text { Mean Age } \\
\text { in Year }\end{array}$ & $\begin{array}{c}\text { Standard } \\
\text { Deviation }\end{array}$ \\
\hline 72 & 27.1111 & 10.22501 \\
\hline \multicolumn{3}{|c|}{ Table 1. Showing No. of Patients, Mean and STD } \\
Deviation in Study Groups
\end{tabular}

Age group distribution is 10 - 20 year, 22 (30.56\%), 21 30 years of age $26(36.11 \%), 31$ - 40 years 14 (19.44\%), 41 50 years $8(11.11 \%)$ and $51-60$ years of age is $2(2.78 \%)$ [Table 2].

Majority of the injuries (53) involved the right side (73.61\%) of hand than left side hand 19 (26.39\%).

\begin{tabular}{|c|c|c|}
\hline Age Group in Year & No. of Patients & $\begin{array}{c}\text { Percentage of } \\
\text { Patient }\end{array}$ \\
\hline $10-20$ & 22 & $30.56 \%$ \\
\hline $21-30$ & 26 & $36.11 \%$ \\
\hline $31-40$ & 14 & $19.44 \%$ \\
\hline $41-50$ & 08 & $11.11 \%$ \\
\hline $51-60$ & 02 & $2.78 \%$ \\
\hline
\end{tabular}

Table 2. Showing Distribution of Age Group in Fingertip Injury

Digits involved about $58.33 \%$ (42 no. of patients) middle finger, index finger 20 (27.78\%), ring finger $8(11.11 \%)$ and little finger is $2(2.78 \%)$ [Table no. 3].

\begin{tabular}{|c|c|c|}
\hline Finger Involved & No. of Patients & $\begin{array}{c}\text { Percentage of } \\
\text { Patients }\end{array}$ \\
\hline Middle finger & 42 & $58.33 \%$ \\
\hline Index finger & 20 & $27.78 \%$ \\
\hline Ring finger & 08 & $11.11 \%$ \\
\hline Little Finger & 02 & $02.78 \%$ \\
\hline Table 3. Shows Distribution of different Finger Involved \\
in Fingertip Injury \\
\hline
\end{tabular}

\section{Study Outcomes and Analysis}

Duration of Surgery: The minimum duration of surgery in our study was 45 minutes and the maximum was 120 minutes. The mean duration of surgery for cross-finger flap was 80.88 mins and for STSG was 54.05 mins. Standard deviation is 18.395 for Group A and 8.024 for Group B. [Table 4]. In crossfinger flap group, there were two surgeries- first at flap insertion and second was on 14 days of post-operative period for flap detachment. For second surgery in Group A, the minimum time was 15 minutes and maximum time was 25 minutes.

$P$ value was 0.097 , which suggests that the operating time for cross-finger flap was more than split thickness skin graft procedure.

\begin{tabular}{|c|c|c|}
\hline Criteria & Group A & Group B \\
\hline Number of Patients & 36 & 36 \\
\hline Mean & 80.8889 & 54.0556 \\
\hline Standard Deviation & 18.39531 & 8.02476 \\
\hline Table 4. Statistical Data Shows Comparison of Duration of \\
Surgery in Minutes in Both Groups \\
\hline
\end{tabular}

Length of hospital stay: Majority of the patients got discharged just after 24 hours of surgery in both groups. Average time for hospital stay in CFF is 25.16 hours and STSG is 24.91 hours. Std. value in Group A is 2117 and in Group B is 2.442 [Table 5].

\begin{tabular}{|c|c|c|}
\hline Criteria & Group A & Group B \\
\hline Number of Patients & 36 & 36 \\
\hline Mean & 25.1667 & 24.9167 \\
\hline Standard Deviation & 2.11795 & 2.44219 \\
\hline \multicolumn{3}{|c|}{$\begin{array}{l}\text { Table 5. Statistical Data Shows Comparison of Length of } \\
\text { Hospital Stay (In Hours) in Both Groups }\end{array}$} \\
\hline
\end{tabular}

Touch sensation- In Group A 72.22\% (26) and in Group B $61.11 \%$ (22) touch sensation returned in operated fingertip between 6 months - 12 months of followup period.

Impaired touch sensation was $10(27.77 \%)$ in Group A and 14 (38.88\%) in Group B [Table 11 and 12]. According to mean 72.222 for Group A and 61.111 for Group B, patients 
were having proper touch sensation [Table 6]. $\mathrm{P}$ value is 0.0041 . It signifies that touch sensation is better in CFF as compared to STSG.

\begin{tabular}{|c|c|c|}
\hline Criteria & Group A & Group B \\
\hline No. of Patients (N) & 36 & 36 \\
\hline Mean & 72.222 & 61.111 \\
\hline Std. Deviation & 45.4256 & 49.441 \\
\hline
\end{tabular}

Table 6. Statistical Data Shows Comparison of Touch Sensation in Both Groups

Pinching was assessed between 6 months and 12 months of followup period after repair. Patient was asked to pinch by repaired finger and thumb on skin of dorsum of own hand. Ability to pinch properly was $28(78.77 \%)$ and poor pinch was $22.22 \%$ in Group A and ability to pinch properly was 12 (33.33\%) and poor pinch 24 (66.67\%) in Group B [Table 11 and 12]. Standard deviation is 42.163 for Group A and 47.809 for Group B [Table 7]. $P$ value is 0.0051 , showing that the functional outcome of pinch is more in CFF as compared to STSG.

\begin{tabular}{|c|c|c|}
\hline Criteria & Group A & Group B \\
\hline No. of Patients (N) & 36 & 36 \\
\hline Mean & 77.7778 & 33.3333 \\
\hline STD Deviation & 42.16370 & 47.80914 \\
\hline $\begin{array}{r}\text { Table 7. Statistical Data Shows Comparison of Pinching } \\
\text { Function of Finger in Both Groups }\end{array}$ \\
\hline
\end{tabular}

Stiffness of finger was assessed by restriction of movement of finger at interphalangeal joint and at metacarpophalangeal joint level of injured finger. Stiffness was absent in $72.22 \%$ (26) and stiffness of finger was noted in $27.77 \%$ (10) in Group A patients and stiffness present in $52.77 \%$ (19) of patients, absence of stiffness of finger $47.22 \%$ (17) in Group B [Table 11 and 12]. According to mean 22.222 for Group A and 72.2222 for Group B, patients were suffering from finger stiffness [Table 8]. $P$ value is 0.00069 . It signifies that stiffness is more in Group B as compared to Group A.

\begin{tabular}{|c|c|c|}
\hline Criteria & Group A & Group B \\
\hline No. of patients (N) & 36 & 36 \\
\hline Mean & 22.2222 & 72.2222 \\
\hline Standard Deviation & 42.16370 & 45.42568 \\
\hline Table 8. Statistical Data shows about Comparison of \\
Stiffness of Finger in Both Groups \\
\hline
\end{tabular}

Further injury to repaired fingertip in normal wear and tear (stress injury) was assessed on followup period between 6 months and 1 year. It was found that minor small pin head size patchy ulcer or abrasion on tip of finger of Group A was $22.22 \%$ (08), absent of minor injury 20 (77.77\%) and in Group B injury on fingertip in normal activity is $61.11 \%(22)$ and absent of any injury found about 14 (38.88\%) [Table 11 and 12]. Durability of fingertip was excellent in Group A as compared to Group B. According to mean, patient 19.444 for Group A and 61.111 for Group B were suffering from further finger injury in normal wear and tear [Table 9]. In this functional outcome, $P$ value was 0.0270 . It signifies that further injury in normal wear and tear was found more in Group A as compared to Group B.

\begin{tabular}{|c|c|c|}
\hline Criteria & Group A & Group B \\
\hline No. of patients (N) & 36 & 36 \\
\hline Mean & 19.4444 & 61.1111 \\
\hline Standard Deviation & 40.13865 & 49.44132 \\
\hline
\end{tabular}

Table 9. Shows Comparison of Further Injury of Fingertip on Normal Wear and Tear in Both Groups

Aesthetic acceptance of patients of both procedures found that in Group A it is 32 (88.88\%) and $08(22.22 \%)$ in Group B [Table 11 and 12]. According to mean 88.888 for Group $A$ and 22.222 for Group B, patients had excellent aesthetic acceptation [Table 10]. $P$ value is 0.1785 , showing that aesthetic acceptation is more in CFF as compared to STSG group.

\begin{tabular}{|c|c|c|}
\hline Criteria & Group A & Group B \\
\hline No. of patients (N) & 36 & 36 \\
\hline Mean & 88.8889 & 22.2222 \\
\hline Standard deviation & 31.87276 & 42.16370 \\
\hline $\begin{array}{c}\text { Table 10. Shows Comparison of Aesthetic Acceptation of } \\
\text { Repaired Fingertip in Both Groups }\end{array}$ \\
\hline
\end{tabular}

\begin{tabular}{|c|c|c|}
\hline Functional Outcomes & $\begin{array}{c}\text { No. of } \\
\text { Patients }\end{array}$ & $\begin{array}{c}\text { Percentage of } \\
\text { Patients }\end{array}$ \\
\hline $\begin{array}{c}\text { Presence of touch sensation of } \\
\text { repaired fingertip. }\end{array}$ & 26 & $72.22 \%$ \\
\hline $\begin{array}{c}\text { Further injury to repaired } \\
\text { fingertip in normal wear and } \\
\text { tear. }\end{array}$ & 08 & $22.22 \%$ \\
\hline Absence of Finger stiffness & 26 & $72.22 \%$ \\
\hline Aesthetic acceptance & 30 & $83.33 \%$ \\
\hline Good Pinching & 28 & $78.77 \%$ \\
\hline
\end{tabular}

Table 11. Showing different Functional Outcome in CrossFinger Flap (Group A)

\begin{tabular}{|c|c|c|}
\hline Functional Outcomes & $\begin{array}{c}\text { No. of } \\
\text { Patient }\end{array}$ & $\begin{array}{c}\text { Percentage of } \\
\text { Patients }\end{array}$ \\
\hline $\begin{array}{c}\text { Presence of touch sensation of } \\
\text { repaired fingertip. }\end{array}$ & 22 & $61.11 \%$ \\
\hline $\begin{array}{c}\text { Further injury of repaired } \\
\text { fingertip in normal wear and tear. }\end{array}$ & 22 & $61.11 \%$ \\
\hline Absence of finger stiffness & 17 & $47.22 \%$ \\
\hline Aesthetic acceptation & 10 & $27.22 \%$ \\
\hline Good pinching & 12 & $33.33 \%$ \\
\hline
\end{tabular}

Table 12. Showing different Functional Outcomes in SplitThickness skin Graft (Group B)

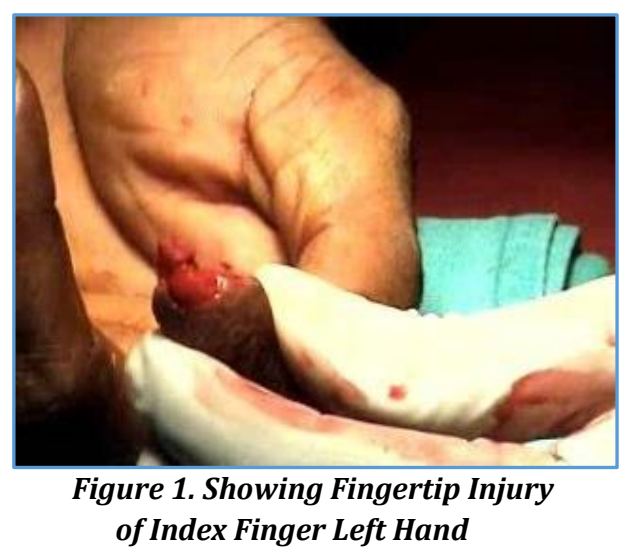

of Index Finger Left Hand 


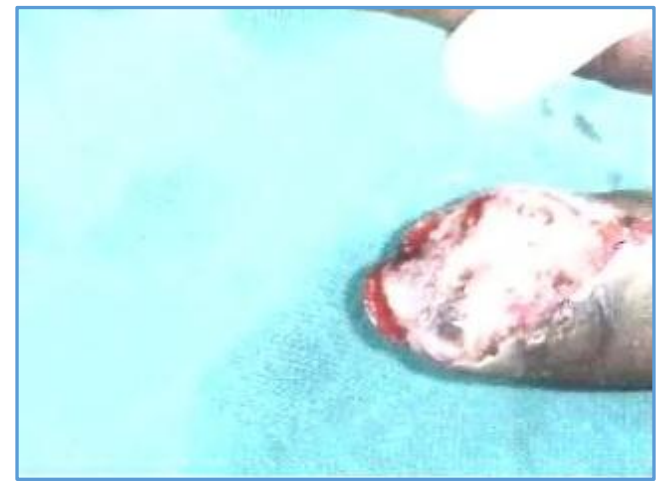

Figure 1a. Fingertip Injury, Index Finger

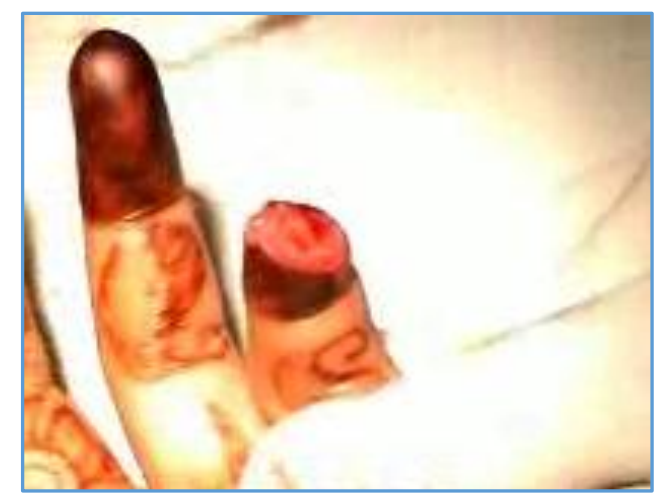

Figure 1b. Little Fingertip Injury of an Adult Female Patient with Tattoo Mark

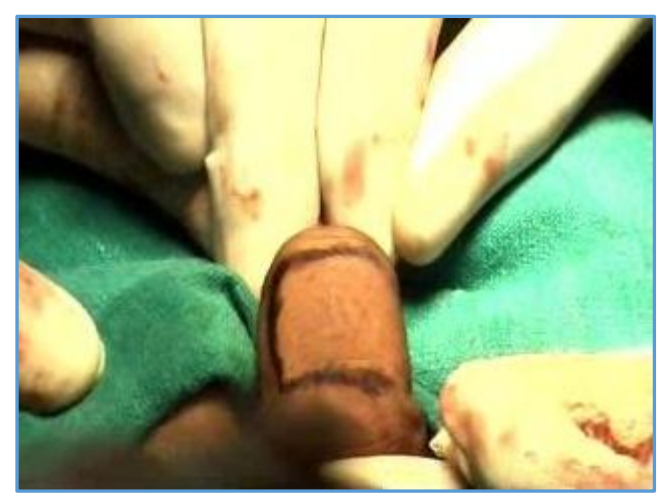

Figure 2. Marking by Methylene Blue Ink on Dorsum of Middle Phalanx for Elevation of Flap to Cover Injured Fingertip

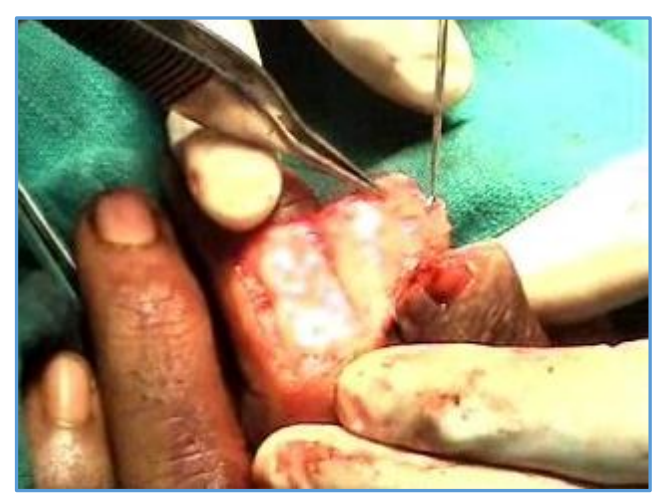

Figure 3. Flap Elevated at the Level of Extensor Tendon Sheath on Dorsum of Finger. Sheath of Tendon is Preserved

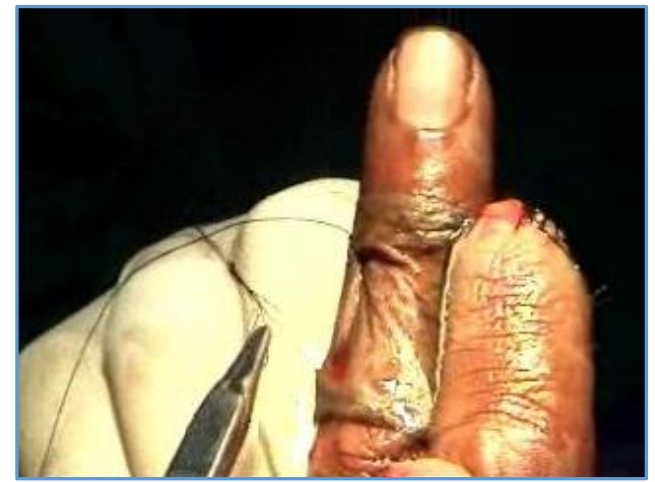

Figure 4. Flap is Inserted to Injured Index Fingertip and Split-Thickness Skin Graft Applied on Dorsum of Raw Area of Middle Finger

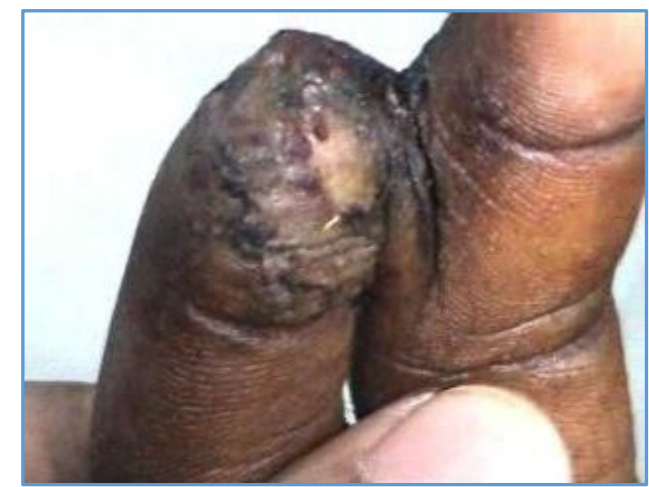

Figure 5. On Post-Operative Day 14, Patient came for Flap Detachment

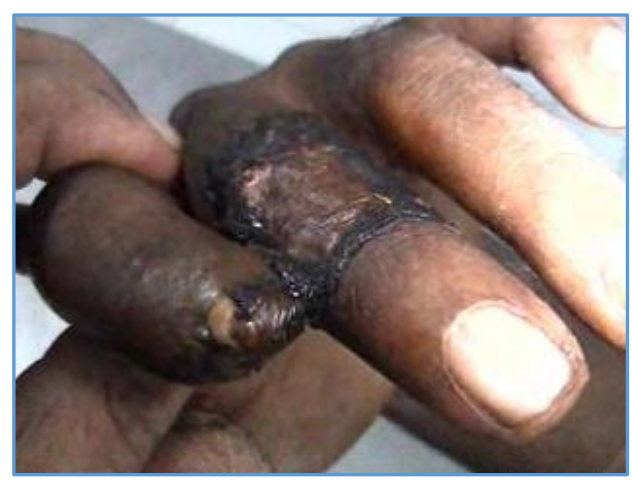

Figure 6. Post-Operative 14th Day, Vascularised, Inserted Cross-Finger Flap for Detachment

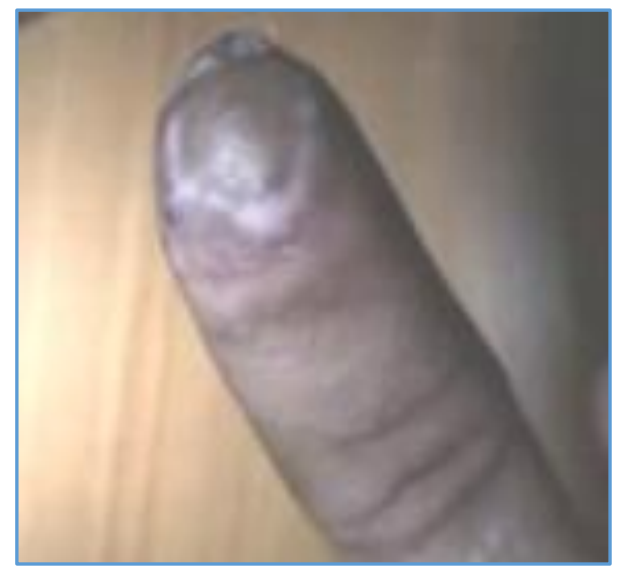

Figure 7. Result of Operated Index Fingertip Injury with Cross-Finger Flap at 6 Months Follow-Up Period 


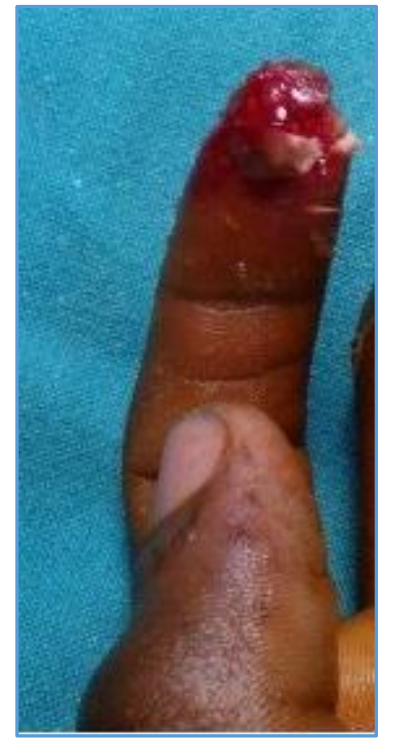

Figure 8. Fingertip Injury for Wound Debridement and STSG

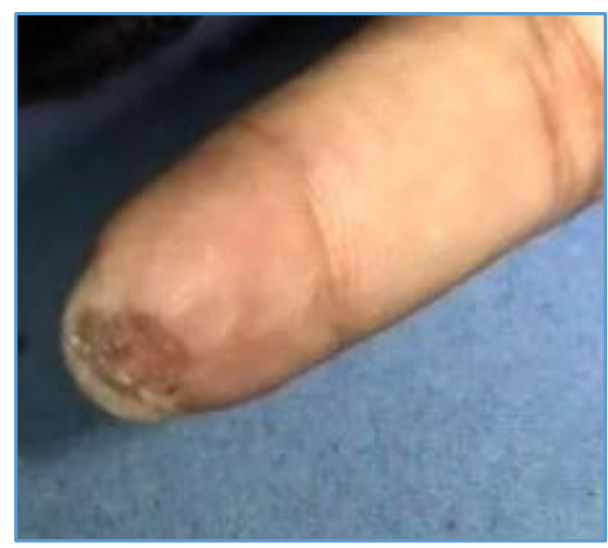

Figure 9. Final Result of Skin Grafted Area of Fingertip Injury

\section{DISCUSSION}

Fingertip is defined as that part of the terminal phalanx distal to the insertion of the extensor aponeurosis on the dorsal surface and deep flexor digitorum tendon on the volar aspect of the finger. About $10 \%$ of all accidents in emergency department are hand injury and fingertip injury are common among them. In recent years, opting the treatment of these injuries has become controversial. Many interesting techniques have been devised to ensure coverage of exposed bone or soft tissue. No definite rule to dictate the choice of treatment modality.

In consultation with patient, every surgeon must choose the type of coverage that appears to be most appropriate for that individual's need.

\section{Function of Hand}

Function of the hand are multiple, though the most important are the sensory function of touch and the function of pretension.

\section{Sensory}

Sensory function are deep and superficial sensation. Superficial sensation is either fine or discriminative (epicritic) or gross (protopathic). It has an essential role in information and discrimination of intensities or qualities and particularly of local specification [Head 1992]. It has a protective role and thus bring about a regional response of defence, the most immediate and least controlled of which is the withdrawal reflex. Deep sensation of hand provides information regarding the position of the skeleton and muscles.

\section{Grip and Prehension}

In the animal world, a variety of organs are adapted for prehension. According to Rabischong, ${ }^{[19]}$ they may be divided into four types: organ that pinch, encircle, push and adhere. Usually animals can utilise only one of these forms of prehension. Man, owing to the multiple possibilities and malleability of his hand, can reproduce all type of pinch from the simple hook to digitopalmar grip.

\section{Classification of Fingertip Injury}

Fingertip injury classify as per Allen as follows,

Allen classification of fingertip injury-

Allen Type 1- Soft tissue injury distal to terminal phalanx. Allen Type 2- An injury at the level of terminal phalanx. Allen Type 3- An injury at the level of the distal phalanx shaft. Allen Type 4- An injury just distal to the distal interphalangeal joint.

In this study, all types of fingertip injuries were taken and treatment options (CFF or STSG) were given to the patient.

The aim of our study was to compare two different methods of surgery, the cross-finger flap and STSG in the treatment of fingertip injury. The primary objective of the study is to assess the functional outcome of patients treated with either of the two procedures.

All the cases were classified according to the Allen Classification, which is the most accepted classification all over the world. All patients were operated and followed up for an average period of 6 - 12 months.

\section{In this Study, it is Noticed that-}

1. Maximum number of fingertip injuries occur in male.

2. In majority of Right hand (73.61\%) is involved as compared to left hand (26.39\%).

3. Duration of surgery is more in Group A as compared to Group B.

4. Average length of stay in hospital in both groups is approximately the same.

5. Sensation of fingertip after both procedures was observed up to 6 months of post-operative period. Touch sensation usually returned early in CFF at 6 months followup period. About $55.55 \%$ of patients percept touch sensation at 6 months of followup period. Two point discrimination was $80.66 \%$ in Group A as compared to Group B.

6. Stiffness of finger during post-operative followup period, finger stiffness was assessed on movement of finger at metatarsophalangeal joint and at interphalangeal joint. Stiffness of operated fingers is more in Group B as compared to Group A patient. But stiffness gradually subsided after physiotherapy of finger in all study groups.

7. After long followup period it was found that minor ulceration and any wound on fingertip on both study groups during normal wear and tear (normal work), 
maximum number and percentage of patients $61.11 \%$ (22) had injury in Group B patients as compared to Group A $22.22 \%$ (8). This injury was more in skin grafted fingertip, may be due to thinning of area and unable to resist the minor trauma during normal work. In CFF group, contour of fingertip was excellent and it provided bulk of tissue to fingertip to resist minor trauma for further injury.

8. Aesthetic appearance of repaired fingertip in crossfinger flap group was better as compared to STSG group. Maximum number of Group A patients were satisfied as compared to Group B.

\section{CONCLUSION}

In this study, following conclusion was drawn

1. Majority of patients were male.

2. Maximum number of patients were in age group of 21 30 years of age (36.11\%).

3. Right hand was more involved in fingertip injury as compared to left hand.

4. Middle fingertip injury was maximum $58.33 \%$ as compared to other fingers.

5. Aesthetic acceptation of patient observed in both procedures was excellent in Group A.

6. Durability of repair of injured fingertip in Group A was better as compared to Group B patient.

7. About functional outcome like sensation, pinch, stiffness of finger, resistance to injury on normal wear and tear of patients treated in different groups, good functional outcome was seen in Group A as compared to Group B.

Overall, it can be concluded that cross-finger flap coverage is an ideal option for treatment of fingertip injury.

\section{REFERENCES}

[1] Krauss EM, Lalonde DH. Secondary healing of fingertip amputations: a review. Hand (N Y) 2014;9(3):282-8.

[2] Quell M, Neubauer T, Wagner M. Treatment of fingertip defect injuries with a semi-occlusive dressing. Handchir Mikrochir Plast Chir 1998;30(1):24-9.

[3] Gonzalez RI, Buncke HJ. Repair of injuries to soft tissues of fingers, primary and secondary reconstruction. J Calif Med 1962;96(5):347-9.
[4] Jackson EA. The V-Y plasty in the treatment of fingertip amputations. Am Fam Physician 2001;64(3):455-9.

[5] Segmuller G. Modification of the Kutler flap: neurovascular pedicle. Handchirurgie 1976;8(2):75-6.

[6] Keim HA, Grantham SA. Volar-flap advancement for thumb and finger-tip injuries. Clin Orthop Relat Res 1969;66:109-12.

[7] Macht SD, Watson HK. The Moberg volar advancement flap for digital reconstruction. J Hand Surg Am 1980;5(4):372-6.

[8] Choughri H, Sommier B, Pelissier P. A technical tip of the O'Brien volar advancement flap for thumb reconstruction. J Plast Reconstr Aesthet Surg 2009;62(6):e176-7.

[9] Tempest MN. Cross-finger flaps in the treatment of injuries to the finger tip. Plast Reconstr Surg (1946). 1952;9(3):205-22.

[10] Cronin TD. The cross finger flap: a new method of repair. Am Surg 1951;17(5):419-25.

[11] Nicolai JP, Hentenaar G. Sensation in cross-finger flaps. Hand 1981;13(1):12-6.

[12] Kisner WH. Cross finger flaps. Am Fam Physician. 1979;19(1):157-60.

[13] Megerle K, Palm-Bröking K, Germann G. The crossfinger flap. Oper Orthop Traumatol 2008;20(2):97102.

[14] Kappel DA, Burech JG. The cross-finger flap. An established reconstructive procedure. Hand Clin 1985;1(4):677-83.

[15] Rabarin F, Cast SY, Jeudy J, et al. Cross-finger flap for reconstruction of fingertip amputations: long-term results. Orthop Traumatol Surg Res 2016;102(Suppl 4):S225-8.

[16] Nicolai JP, Hentenaar G. Two-point discrimination in cross-finger flaps. Handchir Mikrochir Plast Chir 1983;15(4):241-4.

[17] Massart P, Saucier T, Bèzes H. Restoration of the pulp with a homodigital neurovascular flap. Ann Chir Main 1985;4(3):219-25.

[18] Rabischong P. Basic problems in the restoration of prehension. Ann Chir 1971;25(19):927-33.

[19] Allen MJ. Conservative management of fingertip injuries in adults. Hand 1980;12(3):257-65. 